\title{
REVIEW OF THE YEAR: 2062
}

\section{Things can only get better.}

\section{BY JOHN GILBEY}

A 11 in all, 2062 hasn't been such a bad year by modern standards. The aftermath of the Silicon Valley debacle is still with us, of course. You will remember the initial panic last year when a protocol breach at Sunnyvale-based biotech start-up Viral Sand led to a chemoviral release - one that has yet to be contained. Although it has dropped out of public awareness, outside California at least, an extensive area west of Highway 101 remains evacuated as the trees, turf and shrubs towards Mountain View and Palo Alto slowly transmute into, well, silicon. The only winner so far has been local coffee chain Dave's Dangerous Drinks - whose espresso, hand-crafted for the billionaire tech trade, is currently the only substance known to halt the crystalline mayhem.

The major - if ironic - loss of life after the poorly controlled blowout at Armstrong in January led to Project Exodus being halted, pending the long overdue inquiry into excess profit-taking by key contractors for the Lunar Commission. There is, as yet, no date set for a resumption of transfer flights to the colony and the members of the extremist Malthus Faction are again petitioning the World Council Office of Population Management to reintroduce the compulsory Life Quality Selection Program - or 'Death Lottery' as it is commonly known. Critics of the programme point to the hugely biased focus found in the original algorithm back in 2055, which discredited the project and led to the forced euthanasia of the software development team.

A low point for some 500 million people occurred when equipment failures at the Nevada-Arizona SPA (Solar Protein Assembly) facility in April put most of the NorthAm Directorate on short rations for the summer. The loss of production at the height of the summer bloom caused major distribution issues, which led to food riots in a dozen prefectures. A spokesperson for the operators cited the withdrawal of government funding from their corporate security as a contributory factor, fuelling speculation that sabotage - presumably by hardline Malthusians - was involved. NorthAm initially refused to speculate on the number of deaths resulting from starvation and cannibalism, but later reassured the public that the figure was probably only in the "low millions".

Perhaps more worrying are the still

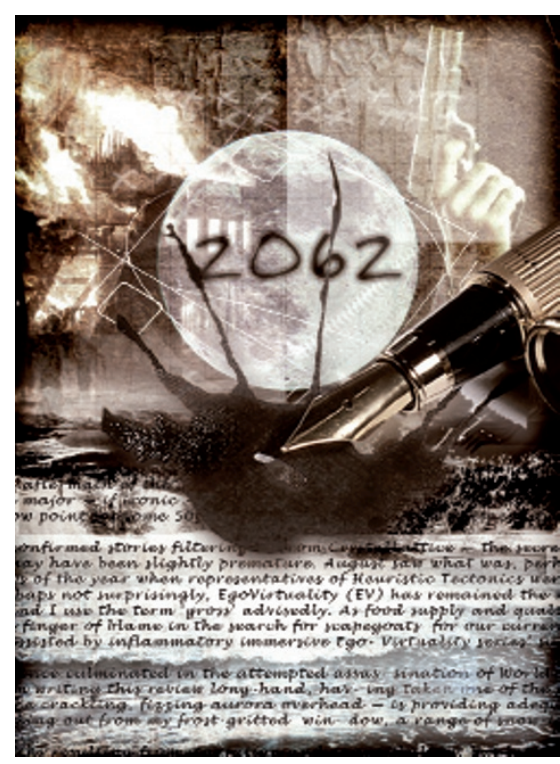

unconfirmed stories filtering in from CrystalLattice - the secretive global host body for science and environmental data - that corruption of its universally adopted femtoarray storage media has invalidated much of the material from the second half of the twentieth century. At their conference in June, the surviving members of the Librarians against Climate Change pressure group politely suggested that, in retrospect, the UN mandated carbon-sink policy - which consigned most of the world's physical libraries and human-readable data stores to the bottom of the Marianas Trench in the late' 40 s - may have been slightly premature.

August saw what was, perhaps, the best news of the year when representatives of Heuristic Tectonics were quoted as saying that "the worst is nearly over". Their analysis of global changes following the surprise impact in 2050 of the asteroid now known as Calamity Jane suggests that less than half of the geological after effects have yet to occur. The East African Rift Sea, now an arm of the Indian Ocean, is slowly stabilizing and some commentators predict that a sustainable fishery may one day be developed on its shores - although why the water is quite so radioactive remains a mystery. The impact on continental, and global, weather patterns is also still under debate: the images
SNATURE.COM

Follow Futures: $\checkmark$ @NatureFutures If go.nature.com/mtoodm of blizzard conditions around Luxor's temples, and the protracted icing of the Nile, during October will remain fixed in the minds of climatologists for years to come.

Perhaps not surprisingly, EgoVirtuality (EV) has remained the major preoccupation of most of the human race during the year, with the earnings of the major networks putting them well above all three of the remaining nation states in terms of gross revenues - and I use the term 'gross' advisedly. As food supply and quality of life have become further restricted, the demand for more and wilder programming has been rampant.

The finger of blame in the search for scapegoats for our current problems has pointed increasingly towards the embattled science community again this year - assisted by inflammatory immersive EgoVirtuality series' such as Rogue EcoScientist, Killer Sex Geek and Science: Greed Machine whose fans allegedly burnt down eleven scientific research institutes during the autumn season. These acts of digi-hormone-fuelled violence culminated in the attempted assassination of World Council Speaker Dorothy Ulaka-Chen during her oath-taking ceremony in November - following the revelation on a popular EV fan channel that she holds a PhD in biology. No one has yet been charged with any of these offences.

I am writing this review long-hand, having taken one of the underground craft courses in handwriting recently adopted by the remaining pockets of academia. This act is, however, one of necessity rather than style, as the regional broadcast energy grid in northwest Europe has failed - hopefully only temporarily. The glow from the culprit - the crackling, fizzing aurora overhead - is providing adequate light for the exercise, I note with a wry smile. Writing helps me blot out both the gnawing hunger and the screams of those local EV addicts who are trapped in their non-operative headsets and faced with reality for first time in many years.

Looking out from my frost-gritted window, a range of snow-laden hills is just visible beyond the stunted forest of gaunt fuel-wood trees. With the urban glow absent, this scene has probably changed little in millennia - a thought that provides a modicum of hope. We'll have these problems fixed any day now, won't we. Won't we...?

John Gilbey is a science writer living in west Wales. His nightmares are his own, but he probably needs to talk to someone about them. 